\title{
Fair Equality of Opportunity in our Actual World ${ }^{1}$
}

John Rawls defined the principle of fair equality of opportunity as the requirement that "those who have the same level of talent and ability and the same willingness to use those gifts should have the same prospects of success regardless of their social class of origin, the class into which they are born and develop until the age of reason."2 This principle, ever since Rawls enunciated it, has been battling a war on two fronts. Looking at things from the beginning of life, it must be conceded that parents have broad liberty to raise their children as they see fit, engaging in a greater or lesser degree of nurturing and advantage giving according to any one of a broad array of permissible childrearing styles. So it seems that, because of this, the social class of one's origin must inevitably have a great influence on one's prospects of success. And if we look at things from the other end, asking what it is that determines whether a child, taking the social circumstances of her early life as given, succeeds in life, we notice that in a meritocratic world her array of skills is the main determinant of her fortune on the job market and thus a heavy influence on her success in life. And yet there's so much more that goes into the cultivation of a skill besides talent and ability, such as being fortunate enough to be taken under the wing of an expert in one's desired field, and this seems to undermine fair equality of opportunity all over again.

What, then, could possibly be the place of fair equality of opportunity in a world of broad parental liberty and meritocracy—i.e. in our actual world? There are

\footnotetext{
${ }^{1}$ I would like to thank Lawrence Blum, Andrew Mason and Kirsten Meyer for reading and commenting on a previous draft of this paper.

${ }^{2}$ John Rawls, Justice as Fairness, ed. Erin Kelly (Cambridge, Mass.: The Belknap Press, 2001), p. 44.
} 
actually two questions here, the specific question depending on whether broad parental liberty and meritocracy are admitted to be part of our world de jure or de facto. I find both questions compelling and seek to answer them both in this essay, because in my view each of those two principles is both morally valid and instantiated in fact. (I will defend this claim in due course.)

One element of my answer will be predictable and boring: broad parental liberty, meritocracy, and fair equality of opportunity can be made compatible by taking each of them to be merely pro tanto valid. But having made this move there is still a great deal to be done. Most urgently, we need to formulate a political morality that contains all three principles. This requires explaining how the conjunction of broad parental liberty, meritocracy, and the fair equality of opportunity can constitute a coherent political outlook. And then, having (hopefully) managed that, it remains to defend that outlook against objections. Those two goals constitute my agenda here.

I begin, in $\S 2$, by arguing that the principles of broad familial liberty and meritocracy are each valid and inescapable. $\S 3$, which follows, is the heart of the essay; it contains my preferred variant of the principle of fair equality of opportunity and an argument for it. The version I endorse is rather narrow, dealing only with the distribution of prospects for desirable jobs and offices - and my defense of it focuses on explaining what is distinctively good about certain jobs. In support for fair equality of opportunity so construed, I appeal to the intuition that there ought to be a fair competition for that good. The rest of the essay is an effort to answer some very powerful, well-formulated objections to the principle of fair equality of opportunity, mostly from Richard Arneson and Andrew Mason. In §4 I confront the luck egalitarian objection that asks why we should adopt a principle that allows prospects for jobs and offices to be affected by talent but not social circumstances, given that 
the two are equally arbitrary from a moral point of view. I argue in response that what counts as the right job for a person depends on what her talents are, and therefore there is no single competition for the distinctive good of the right job but rather innumerable mini-competitions among people with similar talents. §5, meanwhile, addresses the worry that the distribution of jobs and offices shouldn't be regulated by its own principle but rather whatever principle in our political morality that addresses the distribution of goods per se. I respond by pointing out that the ideal of a fair competition is a non-consequentialist ideal and therefore it would make no sense to fold it in with a principle that addresses the distribution of goods. Finally, in $\S 6$, I answer the objection that FEO has unpalatable implications for how parents are morally permitted to raise their children. I argue that the ideal of setting up a fair competition simply has no normative purchase on ordinary individuals; it applies only to states. Consequently FEO has no implications at all for how parents are morally permitted to raise their children. $\$ 7$ concludes.

\section{Broad Familial Liberty and Meritocracy}

In this section I aim to establish that broad familial liberty and meritocracy are each valid and in effect in our actual world. By "our actual world" I mean developed liberal democracies. And by "valid" I mean that they are each part of the true political morality - the true theory of what the state is morally obligated to do. Note that I am not claiming that these principles are part of the true theory of justice. I assume that justice is one of many elements of political morality; the state morally ought to do what is just, but it also morally ought to do other things like make sure everyone drives on the same side of the road. I am simply sidestepping here the 
question of whether broad familial liberty and meritocracy are just. Of course, as G.A. Cohen emphasizes in his own effort to distinguish justice from other interesting questions in political philosophy ${ }^{3}$, the state should strive to be as just as it can while giving other kinds of consideration their due. ${ }^{4}$ This means that in trying to establish that broad familial liberty and meritocracy are elements of the true political morality we must beware of the possibility that they are incompatible with the requirements of justice, as that would constitute a strong counterargument.

As it happens, however, there is a strong case to be made that the state's noninterference with broad familial liberty is a requirement of justice. Allowing family members to interact with each other as they see fit (within certain loose boundaries) is necessary if they are to realize the goods that familial life makes possible, which are some of the most valuable of all goods - namely, the spontaneous selfless provision and receipt of love, assistance, nurturing, companionship, etc. This sort of argument has been made before, and with much greater care and rigor than I can manage here, by other theorists. ${ }^{5}$ I will simply assume that their arguments succeed in establishing that broad familial liberty is a requirement of justice. And as to the real-world situation, I will rest content pointing out that in every developed liberal democracy married couples are in fact granted this broad liberty.

Things are different, however, when it comes to meritocracy, because it would not be so easy to give a justice-based argument for that principle. As I said, however, I aim only to establish that meritocracy is an element of the true political morality. In

\footnotetext{
${ }^{3}$ See his distinction between principles of justice and rules of regulation in Cohen, Rescuing Justice and Equality (Cambridge, Mass.: Harvard University Press, 2008), chs. 6-7.

${ }^{4}$ Ibid., pp. 284, 305.

5 See Harry Brighouse and Adam Swift, "Parents' Rights and the Value of the Family", Ethics 117 (October 2006): 80-108, "Legitimate Parental Partiality", Philosophy \& Public Affairs 37, no. 1 (2009): 43-80, Family Values: The Ethics of Parent-Child Relationships (Princeton: Princeton University Press, 2014), Part Two.
} 
any event, we are getting ahead of ourselves, not having yet given a definition of the principle.

The principle of meritocracy, as I want to defend it, is the claim that jobs and offices should be awarded solely on the basis of the relevant qualifications. Of course it's difficult to define the idea of "relevant qualifications". Supposing, for instance, that most of the clients of Business $\mathrm{X}$ are racists, Business $\mathrm{X}$ might turn a higher profit by making sure that all of its employees are of a certain race. This, on a broad understanding of what a qualifications is, would make race a qualification for employment in business $\mathrm{X}^{6}$

In spite of this problem, I'll adopt the broad understanding. ${ }^{7}$ Specifically, a qualification for a job or office will be any characteristic that would aid an individual in discharging it in a way conducive to the realizing the goals of the organization containing that job or office. We can endorse meritocracy, given this understanding of qualifications, even if we are strongly opposed to discrimination, since we can also maintain that an anti-discrimination principle is a weightier element of the true political morality.

As to why we should endorse meritocracy, so understood, my answer is that a system that allocates jobs and offices based on qualifications promotes economic growth better than any other possible system, holding fixed the other relevant features of society such as its educational system, wage structure, etc. ${ }^{8}$ Overall it is conducive

\footnotetext{
${ }^{6}$ For an interesting discussion of this problem, see Andrew Mason, "Equality of Opportunity, Old and New", Ethics 111 (July 2001): 760-81.

${ }^{7}$ One benefit of going this route is avoiding the tricky question of whether it is possible to identify, for any given job, a narrower sense of qualifications for it-narrower in the sense of focusing exclusively on the possession of the relevant skills. For a skeptical view on this, see Iris Marion Young, Justice and the Politics of Difference (Princeton, N.J.: Princeton University Press, 1990), pp. 200-06.

${ }^{8}$ There could be circumstances in which this would fail to hold, as Andrew Mason has pointed out to me. If there is a group of people that is underrepresented in a certain profession due to historical discrimination, it might maximize productivity in the long run to use a system of positive discrimination, at the cost of meritocracy, as a way of increasing that group's representation in the profession. This would be the case if such positive discrimination could be expected to encourage
} 
to economic growth that organizations achieve their goals, since those goals generally include increasing the production of some good or service. If we add to this the principle that the state is morally obligated to promote economic growth ${ }^{9}$ then we have in hand a complete argument for meritocracy as an element of the true political morality. And surely most of us do believe that the state has this obligation.

Economic growth in general has the effect of reducing inequality ${ }^{10}$ and unemployment and of increasing well-being, and most of us would accept, with respect to at least one of these goals, that the government is obligated to pursue it.

Of course these goals often come into conflict with other goals, and I don't mean to say that the former goals are always more morally urgent. I am defending meritocracy here as pro tanto valid. If meritocracy were an overriding principle, then the right thing to do would be to simply conscript the most qualified person for each job or office. But this seems highly objectionable.

This raises the question of how meritocracy can be put into effect, in a morally permissible way, given its pro tanto status. The best answer, I think, is that it can be put into effect by instituting a free market. Free market societies must be meritocracies by and large,${ }^{11}$ since organizations generally pursue their goals to the best of their ability and this, by the earlier definition of 'qualification', requires hiring the most qualified people to fill vacancies. Now there is probably a more powerful argument for the free market than its instrumental role in realizing meritocracy, but that's beside the point. My agenda with respect to meritocracy is twofold: to establish

\footnotetext{
younger members of that group to pursue that profession, thereby unlocking productive potential that would otherwise have gone unused.

${ }^{9}$ This utility-promotion principle is not intended as a principle of distributive justice; it is intended to stand alongside whatever the true principle(s) of distributive justice is/are. So if distributive justice takes something other than utility as its currency, or if it tells us to sacrifice maximization of the currency to some extent if that's necessary to achieve some distributive pattern, that's no objection to the utility-promotion principle. I thank Andrew Mason for urging me to be clear about this.

${ }^{10}$ Thomas Piketty, Capital in the $21^{\text {st }}$ Century, trans. Arthur Goldhammer (Cambridge, Mass.: Harvard University Press, 2013).

${ }^{11}$ By "must be" I mean "it would stand to reason that".
} 
its moral validity and to show that it is in effect in our actual world. I mention the free market only to persuade the reader that our actual world must be, by and large, a meritocracy. Having made that argument, and having argued earlier for the moral validity of the principle of meritocracy, I'll rest content.

\section{An Argument for Fair Equality of Opportunity}

In this section I intend to defend the principle of fair equality of opportunity (FEO) and show how it can be part of a coherent political outlook that also contains broad parental liberty and meritocracy. First, however, we need to know just what claim FEO is.

On the statement of it from Rawls that I quoted at the outset, it says something about how "prospects for success" should be distributed. However, it must be said that Rawls is quite inconsistent on the matter of what the currency ${ }^{12}$ of FEO is. In other places Rawls puts forward FEO as a principle regulating the distribution of prospects for "culture and achievement"13, "income and wealth"14, and "advantaged social positions"15. And for Rawls FEO is embedded within a broader principle, the second principle in his two-principle theory of justice, that says,

social and economic inequalities are to be arranged so that they are... attached to offices and positions open to all under conditions of fair equality of opportunity, ${ }^{16}$

\footnotetext{
${ }^{12}$ By "currency" I mean that which is to be distributed.

${ }^{13}$ A Theory of Justice, pp. 73, 74.

${ }^{14}$ Ibid., p. 74.

15 Ibid.

${ }^{16}$ Ibid., p. 266.
} 
thus suggesting that FEO is to directly regulate the distribution of offices and positions and regulate the distribution of social and economic inequalities only indirectly.

I don't know what version of FEO Rawls really meant to endorse, but I've argued in another essay that the most plausible version of FEO will take only positional opportunities as its currency. ${ }^{17}$ A positional opportunity is an opportunity for a good such that improving one's opportunity to access that good necessarily comes at the cost of diminishing someone else's opportunity to access that good. Positional opportunities are, to put it simply, opportunities to access goods that are in limited supply.

That being the case, we should reject any version of FEO that takes as its currency prospects for culture and achievement or income and wealth, since we can make more of all of those things. ${ }^{18}$ One currency that emerges as quite appropriate, by contrast, is opportunities for jobs and offices, which is pretty close to Rawls's "offices and positions". Although we can affect the number of opportunities for jobs and offices, most obviously by stimulating or depressing economic growth, opportunities for jobs and offices are in many circumstances positional-for-practical-purposesmeaning that we can find ourselves in a position where there's nothing we can do to make more of them — which I've argued is good enough to make such opportunities a proper currency for FEO. ${ }^{19}$

\footnotetext{
${ }^{17}$ Benjamin Sachs, "The Limits of Fair Equality of Opportunity", Philosophical Studies 160:2 (2012):323-43 at 335-40.

${ }^{18}$ This isn't to say that there is no competition for these goods. Rather, these are goods for which we compete and of which we can make more. Thanks to Lawrence Blum for pushing me to be clear about this.

${ }^{19}$ Ibid., p. 340. As to whether opportunities for "social positions" constitute a proper currency for FEO, I'm not sure what to say, since my grasp of what a social position is is a bit hazy. But FEO can have more than one kind of currency, and I simply want to establish that opportunities for jobs and offices should be one such kind.
} 
Knowing this much about FEO, a clearer picture of the relationship between meritocracy and FEO begins to emerge: Since meritocracy regulates the distribution of jobs and offices themselves, saying that FEO regulates the distribution of opportunities for jobs and offices is equivalent to saying that FEO regulates the distribution of prospects for succeeding in the meritocracy.

But the picture is not yet clear enough. In order to fully specify a version of FEO we have to fill in the timing variable in addition to the currency variable. That is, we have to say at what time prospects for doing well in the meritocracy should be equal. I've argued elsewhere that FEO is most plausible when understood as requiring that prospects be equal at one time, as opposed to perpetually or intermittently. ${ }^{20}$ Specifically, prospects should be equal among those entering majority at a given time. This dovetails nicely with the idea that FEO should be understood as opportunity to do well in the meritocracy, since the meritocracy is a non-issue for minors, supported as they are by their parents or some other guardian.

While I've argued elsewhere that the currency and timing variables should be filled in in the way I've suggested here, I've never before argued that FEO is a true principle of political morality. All I've done elsewhere is show that my preferred version of FEO avoids some objections that doom other versions. But having gained a better grasp of the place of FEO in a meritocratic world, I now feel able to articulate with some precision just what it is about FEO that should appeal to us. I take on this task for the remainder of this section. In $\$ 4$ I return to the job of making FEO more precise, arguing there for a particular stance regarding among which individuals opportunities for jobs and offices should be equal at the time of majority.

20 “The Limits of Fair Equality of Opportunity", pp. 327-35. 
To understand the moral force of FEO we need a better grasp on what's good about the thing it distributes, namely opportunities for jobs and offices. The first thing to say here is that opportunities for jobs and offices are merely instrumentally good; they are good because the possession of such opportunities leads to the possession of jobs and offices themselves. Now one might ask, as Richard Arneson ${ }^{21}$ and Stephen Kershnar ${ }^{22}$ have, why we should adopt a principle regarding the distribution of a merely instrumental good when we could instead adopt a principle regarding the distribution of the good for which it is an instrument. So I want to say something about this before discussing what is good about jobs and offices.

I am taking as meritocracy as given, based on the argument I gave in $\S 2$. This amounts to taking as given a principle for distributing jobs and offices. The argument for meritocracy was not based on an analysis of the good of a job or offices. So it can't be accurately said that we've already adopted a principle that is suitable to the kind of good that a job or office is. Rather, the argument for meritocracy was based on 1) the observation that distributing jobs and offices in a certain way is conducive to reducing inequality and unemployment and to increasing well-being and 2) the principle that the state is morally obligated to pursue at least one of these goals. So the moral heart of the argument for meritocracy comes from a moral analysis of the purpose of the state (which I breezed through), not a moral or evaluative analysis of jobs and offices. ${ }^{23}$ Nevertheless, jobs and offices are apt for this kind of analysis, because they are indeed good. The question is this: Once we've produced this

\footnotetext{
${ }^{21}$ Arneson, "Equality of Opportunity Defended and Recanted", Journal of Political Philosophy 7 (1999): 488-97 and "Equality of Opportunity: Derivative not Fundamental", Journal of Social Philosophy 44 (Winter 2013): 316-330 at 321-2 and 326-7.

${ }^{22}$ Kershnar, "Why Equal Opportunity is not a Valuable Goal", Journal of Applied Philosophy 21: 15972.

${ }^{23}$ Which is a good thing, since a moral or evaluative analysis of jobs and offices would certainly not lead to the conclusion that they should be distributed meritocratically. This point has been argued for in Mason, "Equality of Opportunity, Old and New" and in Norman Daniels, "Merit and Meritocracy," Philosophy and Public Affairs 7, no. 3 (1978): 206-23.
} 
analysis, what do we do with it? We can't use it to derive a principle for regulating the distribution of jobs and offices; we already have one of those. ${ }^{24}$ The best we can do, this being the case, is to use it to derive a principle for regulating the competition for jobs and offices. Once we've noticed that jobs and offices are competed for, as opposed to simply being awarded, it becomes possible to understand the competition for them as being a potential bearer of morally good or bad qualities. So we have a nice match: we have a moral/evaluative analysis of a good (the analysis of the good of a job or office, yet to be produced) and a feature of society that regulates the distribution of that good and seems apt for regulation via a moral principle. So it seems only natural to put the two together, deriving the principle from the analysis.

So much for the question of why there should be a principle regulating the distribution of opportunities for jobs and offices. We can now, at last, move on to the question of what is good about a job or office.

There are, no doubt, many right answers to this question. I will focus on establishing just one of them. My view is that if we can agree that this is one of the goods of a job or office, then we should be able to agree on FEO as formulated earlier in this section.

I begin with a clarification: the good that I want to identify isn't one that attaches to jobs or offices per se; rather it attaches to the right job or office, in a certain sense of "right" that I will specify.

Next, I want to call attention to a distinctive kind of good - the good of exercising one's refined and fulfilled talents. Rawls describes that good this way:

\footnotetext{
${ }^{24} \mathrm{Or}$, rather, we could, but it would be worth our time to do so only if we thought that the derived principle might have a chance of outweighing the principle of meritocracy. But I assume that we're confident that it won't.
} 
Other things equal, human beings enjoy the exercise of their realized capacities (their innate or trained abilities), and this enjoyment increases the more the capacity is realized, or the greater its complexity. The intuitive idea here is that human beings take more pleasure in doing something as they become more proficient at it, and of two activities they do equally well, they prefer the one calling on a larger repertoire of more intricate and subtle discriminations. ${ }^{25}$

It's possible to ground an argument for FEO in the claim that this kind of good can be realized in the carrying out of a job or office. Robert Taylor makes an argument like this. ${ }^{26}$ But an argument of this sort is vulnerable to Arneson's insight that this distinctive sort of good can be realized by means other than the carrying out of a job or office. $^{27}$

Fortunately, though, we can make an argument based on Rawls's analysis of this particular good and inspired by Taylor's argument but immune to Arneson's objection. Assuming one is going to work for a living during one's adulthood, one's job or office determines how one will spend half of one's waking adult life. And the distinctively bad outcome that this situation makes possible is being consigned to spend this time engaged in an activity that doesn't call upon one's refined and fulfilled talents. There is a distinctive kind of soul-crushing misery that accompanies suffering this fate - the kind of misery that many early $20^{\text {th }}$-century social critics had in mind when condemning the assembly line. ${ }^{28}$ It is a correlate of the distinctive good Rawls identified, but is not its mere absence. In fact, a single life—indeed, a single day of a single life - can contain the realization of both the good and its negative correlate. So even if one has opportunities, outside of work, to exercise one's refined

\footnotetext{
${ }^{25}$ A Theory of Justice, p. 374.

${ }^{26}$ Taylor, "Self-Realization and the Priority of Fair Equality of Opportunity", Journal of Moral Philosophy 1 (2004): 333-47; see esp. pp. 340-1.

${ }^{27}$ Arneson, "Equality of Opportunity: Derivative not Fundamental", pp. 320-1. Taylor anticipated this objection ("Self-Realization and the Priority of Fair Equality of Opportunity", p. 341), but in my view didn't do enough to defuse it.

${ }^{28}$ One possible mechanism, connecting the having of a non-challenging job to being unhappy, is letting one's mind wander. Letting one's mind wander seems to cause unhappiness, and whether an individual's mind is wandering at any particular moment is a better predictor of whether that individual will be happy at that moment than the activity in which that individual is engaged. See Matthew A. Killingsworth and Daniel T. Gilbert, “A Wandering Mind is an Unhappy Mind”, Science 330, no. 6006 (2010): 1924-31.
} 
and fulfilled talents - in hobbies, for instance — that merely counterbalances, as opposed to undermines, the misery one is likely to experience if one's job doesn't make use of one's refined and fulfilled talents. No good is so excellent such that the time spent realizing that good makes it not-bad to spend half of one's waking adult life doing something that one finds boring.

My conclusion is that there is a particularly brutal kind of bad that one avoids only by obtaining the right kind of job or office — one that calls upon one's talents in the way specified. ${ }^{29}$ So in the end I do not actually have anything original to say about the good of the right job or office; rather, I have something to say about the bad of the wrong job or office. But this will do just as well for grounding an argument for FEO.

The argument will begin by noting that if our society's basic structure is going to inflict a serious harm on various individuals then it matters morally how it is determined who suffers that harm. Of course the harm in this case is attached to jobs and offices, and we already have a principle for distributing jobs and offices. But, as I argued earlier, it's plausible to suppose that our evaluative analysis of jobs/offices can be appropriately deployed to ground a principle regulating opportunities for jobs or offices. Now since jobs and offices are positional-for-practical-purposes, so is the opportunity to avoid getting harmed in the distinctive way associated with ending up in the wrong job or office. Absent special circumstance, it seems that everyone should have an equal opportunity at the age of majority — that is, before the time at which they being to engage in activities for which they can be held responsible and which might affect their opportunity_- to avoid this harm. Securing an equal

\footnotetext{
${ }^{29}$ The closest Rawls comes to acknowledging this bad is his recognition of the good of "meaningful work" (A Theory of Justice, pp. 257, 464). Rawls seems to believe that we could build a society in which everyone has meaningful work (ibid., p. 464) but fails to explain how this is achievable without violating the principle of meritocracy. (Of course Rawls rejects "meritocracy", but what he means by that term is a far cry from what I mean by it; he has in mind a principle that distributes opportunities for jobs and offices unequally in accordance with individuals' unequal possession of natural and social advantages (ibid., pp. 91-2).)
} 
opportunity means putting in place a level playing field in the competition to avoid the distinctive harm of the wrong job/office. ${ }^{30}$ That is what FEO requires, and consequently FEO inherits moral appeal from the compellingness of the idea of a level playing field.

Notice that the idea of a level playing field is applicable only when we're talking about distributing opportunities for jobs and offices; it is entirely irrelevant to the project in which employers are engaged—namely the project of distributing the jobs and offices themselves. (Think of how the idea of a level playing field is applicable when setting up a race but not applicable to awarding medals once the race has been run.) So my defense of FEO doesn't commit me to aligning myself with any principle regarding the distribution of jobs and offices. The principle of careers open to talents is such a principle, the way I understand it: it requires that employers fill their vacancies in a non-discriminatory way. So while Rawls endorsed careers open to talents alongside FEO, I am not committed to doing so. I find this a relief, since Arneson raises very compelling worries about careers open to talents alongside his objections to FEO. ${ }^{31}$

\section{The Luck Egalitarian Objection to FEO and the Question of Scope}

Having argued for my preferred version of FEO I am now in a position to respond to some very important, well thought-out objections to the principle. The first objection concerns the scope of the principle; that is, the set of individuals among whom opportunities are to be equalized. Rawls specified that opportunity should be equal among those who are equal in terms of talent and willingness to put forth effort. A

\footnotetext{
${ }^{30}$ I expand on the idea of a level playing field in "The Limits of Fair Equality of Opportunity".

${ }^{31}$ Arneson, “Against Rawlsian Equality of Opportunity”, pp. 104-7; see also pp. 92-3.
} 
principle crafted in this way requires the state to nullify the influence on opportunity of anything aside from talent and willingness to put forth effort. As Rawls emphasized, this means that the state should nullify the effects of the social circumstances of one's birth on one's opportunity level, which is a morally appealing goal for the state to take up given how such circumstances are arbitrary from a moral point of view. ${ }^{32}$ The objection, however, is that the distribution of talents is morally arbitrary as well, and so if there is a case for neutralizing the effects of social circumstances due to their moral arbitrariness then there should be a case for neutralizing the effects of talent. ${ }^{33}$ So a more plausible version of FEO would have as its scope individuals who are equal in terms of effort alone. Call this the 'luckegalitarian objection'.

A sound response to this objection emerges when we recall what the distinctive good of the right job or office is - namely, the avoidance of the distinctive bad of being stuck spending half of one's waking adult life engaged in an activity that doesn't call on one's refined talents. For people with musical talent, achieving that good means having a job as a musician. For athletic people that means having a job as an athlete. And so on for the other kinds of talent. ${ }^{34}$ Consequently "doing well in the meritocracy", which is what FEO requires that there be equal opportunity for, means something different to each person depending on her talents. Therefore, there

\footnotetext{
${ }^{32}$ A Theory of Justice, pp. 63-5.

${ }^{33}$ Richard Arneson, "Against Rawlsian Equality of Opportunity", Philosophical Studies 93, no. 1 (1999): 77-112 at 93-7. One response to the luck egalitarian objection, the effectiveness of which I won't assess here, is the denial of the possibility of identifying an individual's talents independent of her social circumstances. This is Lesley Jacobs's response; see his Pursuing Equal Opportunities (Cambridge: Cambridge University Press, 2004), ch. 3. Matthew Clayton suggests, in addition, that even if talents and social circumstances could be neatly pulled apart in theory, it would be a violation of political liberalism to build that distinction into a conception of justice since such conceptions should not rely for their institutionalization on distinctions and measurements that will be controversial in practice, as will any claim to the effect that such-and-such an amount of X's lot in life is a result of her talent as opposed to her circumstances (or vice-versa). See Matthew Clayton, "Rawls and Natural Aristocracy", Croatian Journal of Philosophy 1, no. 3 (2001): 239-59 at 257-8.

${ }^{34}$ I oversimplify here, speaking of people as if they have only one talent each. I don't really mean to suggest that this is the case.
} 
is no sense to be made of a talent-insensitive version of equality of opportunity; equality of opportunity has to be relative to talent.

This means that what we might casually call the "competition" for jobs and offices is really a cluster of mini-competitions among people with similar talents. That's why it makes no sense to propose that the principle of equality of opportunity for jobs and offices should not be relativized to talent.

I suspect that the reason why this response to the luck-egalitarian objection has not been made before is that Rawls set us down the wrong track in constructing a defense of his talent-sensitive version of FEO. Curiously, his comments, excerpted above in $\S 3$, regarding the good of being able to exercise one's subtle and developed talents formed no part of his argument for FEO. Rather, Rawls seems to identify the good whose distribution FEO was meant to regulate - and thus presumably the distinctive good of a job or office — as "authority and responsibility" 35 and "the realization of self which comes from a skillful and devoted exercise of social duties." ${ }^{36}$ Although Rawls doesn't elaborate on these comments, one could be forgiven for thinking that Rawls takes the distinctive good of a job or office to be its affording one the opportunity to skillfully execute the duties of some publiclyrecognized office. This being the case, the luck egalitarian can claim, at least somewhat plausibly, that the distinctive good of a job or office is going to be closed off to certain people purely in virtue of their talent because not everyone has the necessary talent to go into public service. The luck egalitarian could even allow us to expand our notion of publicly-recognized office, so that it includes other professions, outside the public service, that are generally recognized as socially necessary, such as medicine, law, and teaching, and point out that we are still forced to the same

\footnotetext{
${ }^{35}$ A Theory of Justice, p. 53.

${ }^{36}$ Ibid., p. 73 .
} 
conclusion: that FEO offers absolutely nothing to certain people, namely those who lack a certain set of talents. ${ }^{37}$

Again, however, we can respond by conceding for the sake of argument that not everyone is born with the talent necessary for eligibility for public service while insisting that everyone is born with some talent or other. In other words, no one is born to do unskilled labour (though there is unskilled labour to be done and someone has to do it, which is the whole problem). So FEO, understood as requiring equal prospects for succeeding in the meritocracy, does indeed offer something to everyone: it offers them a chance, on a par with everyone else of similar talents, to access the jobs and offices that call on the skillful exercise of the developed versions of those talents.

Still, however, while (hopefully) conceding that FEO so understood offers something to everyone, a luck egalitarian is likely to worry that it nevertheless offers more to the more talented. If in speaking of "equally talented" people the principle is referring to people who have the same kind of talent and the same amount of itwhich is exactly how we should understand it, I maintain - then that principle will not seek to equalize prospects among those with unequal amounts of the same talent. In other words, it will allow unequal talent to develop into unequal skill. And since skill is rewarded in a meritocratic world, FEO allows for a situation in which moretalented people end up in a better position than less-talented people with respect to avoiding the distinctive bad we've been talking about. ${ }^{38}$

To arrive at an adequate response to this worry, we need to take a closer look than we have thus far at the distinctive bad of having a job that doesn't call upon the

\footnotetext{
${ }^{37}$ This way of putting the luck egalitarian objection is suggested in Arneson, "Against Rawlsian Equality of Opportunity", pp. 81-3. Thomas Pogge, too, raises a criticism along these lines, in his Realizing Rawls (Ithaca, N.Y.: Cornell University Press, 1989), p. 171.

${ }^{38}$ I thank Kirsten Meyer for pushing me to address this objection.
} 
skillful use of one's developed talents. One obvious aspect of this bad that I've yet to point out is that it comes in degrees. In particular, a job can call on one's developed talents while requiring a more or less skillful exercise of them. Or to put this more straightforwardly: among challenging jobs some are more challenging than others. And how challenging a job is depends on the skillfulness of the person trying to perform it.

Consequently, there's a way in which extra skill—and by extension, extra talent - is a disadvantage. For any given job, it will be less challenging for a particular person the more of the relevant skill she possesses. So for any given job, it's better to be one of the less-talented people to get it, all else being equal. (I assume that in a meritocratic world the least-skilled people who perform any given job are still skilled enough to perform it competently.)

Here is an illustration. Suppose there are two people who are skilled enough to be competent surgeons, and that they each get a job whose sole function is the performing of appendectomies. One of these people, I'll stipulate, has skill to spare. Performing appendectomies is, for this person, experienced only as somewhat of a challenge. For the other person, by contrast, it is the perfect challenge: she can do it well, but only by mustering all the mental and physical resources she has at her disposal. All else being equal, I submit that the latter surgeon has more fully avoided the distinctive bad of spending her working life doing something that doesn't call on the skillful use of a developed talent.

The phenomenon that the above scenario is supposed to represent is a very real one in our society. It is all too common for highly credentialed job candidates to wind up in positions for which they are overqualified. This is what happens when higher education becomes an expectation as opposed to a bonus. 
What we should infer from all this, I conclude, is that in a meritocratic world where FEO is in place, the more talented will indeed have better chances of getting any given job but will also get less out of any given job than the less talented. Or to put this more carefully, the more talented will have a better chance of avoiding the worst outcome - having to work a job that doesn't call on one's refined talents at all — but a worse chance of obtaining the best outcome, namely getting a job that makes just the right call on one's refined talents.

\section{The Separate Principle Objection}

Another objection to FEO begins by accepting, at least for the sake of argument, that there is a distinct kind of good that attaches to holding a job or office. I've identified that good as the avoidance of a bad—namely the bad of being stuck in a job that doesn't call upon one's refined talents — while Rawls, as we saw earlier, identifies that good as "the realization of self which comes from a skillful and devoted exercise of social duties," and other defenders of FEO offer their own proposals regarding the identity of this good. ${ }^{39}$ The objector grants this but then asks why opportunities for this good, which presumably is just one among many, should be distributed according to their own principle. ${ }^{40}$ Call this the 'separate principle' objection.

This principle is often raised in the same breath as a related one - the objection to the idea that FEO should be lexically prior to whatever principle

\footnotetext{
${ }^{39}$ Seana Valentine Shiffrin, for instance, identifies it as the good of self-realization. See Shiffrin, "Race, Labor, and the Fair Equality of Opportunity Principle", Fordham Law Review 72 (2004): 1643 75.

${ }^{40}$ Arneson, “Against Rawlsian Equality of Opportunity”, pp. 97-100, "Equality of Opportunity: Derivative not Fundamental”, pp. 321-2; Harry Brighouse and Adam Swift, "Equality, Priority, and Positional Goods", Ethics 116 (2006): 471-97 at 484-5.
} 
regulates the distribution of the rest of the goods. This objection is generally raised specifically against Rawls, according to whom FEO should be lexically prior to the difference principle, which regulates the distribution of other goods. ${ }^{41}$ But this related objection can be set aside, since I have no intention of suggesting that FEO should be prior, never mind lexically prior, to any other principle.

Back, then, to the issue at hand: Why should there be a separate principle regulating the distribution of opportunities for the particular kind of good that attaches to jobs/offices? The key to answering this objection is to remember that FEO regulates the distribution of opportunities for a certain kind of good, whereas the distribution of the good itself is regulated, we are assuming, by the principle of meritocracy. ${ }^{42}$ Furthermore, there was nothing in my defense of FEO that suggested that there is something good—something non-instrumentally good, specificallyabout opportunities for the distinct good of the right job/office. So FEO isn't actually a principle for regulating the distribution of a good. Therefore, of course the principle that regulates the distribution of such opportunities should be distinct from the principle that regulates the distribution of goods.

This way of answering the separate principle objection naturally raises a further question: Why should we be worried about the distribution of something that is not non-instrumentally good? To answer this challenge we need to recall what the argument was in the first place for endorsing FEO: it is a way of instantiating the moral ideal of a level playing field. Importantly, this makes FEO a nonconsequentialist moral ideal. This, again, should make clear why FEO should be a

\footnotetext{
${ }^{41}$ Though Rawls later seemed to retract this claim. See Raws, Justice as Fairness, p. 163n. For a defense of the lexical priority of FEO against this objection, see Shiffrin, "Race, Labor, and the Fair Equality of Opportunity Principle".

42 This of course raises the question of why we should endorse the principle of meritocracy instead of opting to have the distribution of the distinct good of a job/office regulated according to whatever principle regulates the distribution of goods per se. Mason attempts to meet this challenge in "Equality of Opportunity, Old and New", though his argument for meritocracy is quite different from mine and therefore I don't endorse his way of meeting the challenge.
} 
separate principle instead of getting folded in with whatever principle regulates the distribution of goods. ${ }^{43}$

This way of responding to the separate principle objection forces Arneson, the originator of that objection, to confront a dilemma. If he accepts, in principle at least, that the true political morality might contain principles grounded in nonconsequentialist moral ideals, then he has to argue that there is no moral appeal to the ideal of a level playing field. To my knowledge he has never attempted to make such an argument. On the other hand, if he rejects in principle the possibility of the true political morality containing a principle grounded in a non-consequentialist moral ideal, then it will become clear that the separate principle objection is really just a veiled assertion of consequentialism in political morality — the claim that all political ideals are grounded in evaluative considerations. It's possible, of course, that consequentialism in political morality is the truth, and I have no intention here of arguing to the contrary. But Arneson's objection to FEO becomes rather uninteresting if it turns out that he is simply unwilling per se to consider the viability of a non-consequentialist political morality. ${ }^{44}$

\section{The Childrearing Objections}

\footnotetext{
${ }^{43}$ It also functions as a response to Clayton's objection to FEO, which is that if we find prioritarianism appealing, as Rawls does, then we should be happy to have the distribution of opportunities be regulated by the difference principle, which is prioritarian, thus eliminating the need for FEO (Clayton, "Rawls and Natural Aristocracy"). Again, however, FEO as I understand is a purely moral ideal, and therefore its function cannot be co-opted by a prioritarian (or egalitarian, or sufficientarian, or [...]) principle for the distribution of goods.

${ }^{44}$ One thing we can say for sure is that the present-day Arneson is a consequentialist about political morality. (See his endorsement of the idea that justice requires "the greatest possible degree of fulfillment of the morally supreme goal", which is enhancing the quality of people's lives: Arneson, "Equality of Opportunity: Derivative Not Fundamental", p. 316.) But this is insufficient to establish that his objection to FEO is nothing more than an assertion of consequentialism.
} 
I want to turn again to the relationship between FEO and broad parental liberty. FEO has been subjected to two powerful objections based on its implications for how parents should raise their children. I call them the 'childrearing objections'.

The first childrearing objection is Arneson's and constitutes another worry about the scope of FEO. FEO insists that opportunities be equal among those equal in talent and willingness to put forth effort. That has the effect of treating talent and willingness to put forth effort as given and beyond the reach of the demands of political morality, or at least beyond the reach of anything FEO has to say about those demands. We have already seen why it might be thought troublesome to take talents as given; this was the origin of the luck egalitarian objection. In addition, it might be thought troublesome to take the willingness to put forth effort as given. One determinant of an individual's willingness to put forth effort is her ambition, which is affected by how she is raised and socialized. For instance, if she is raised and socialized to think that the only appropriate role for her in society is to be a homemaker, then she is likely wind up lacking the ambition to do anything else. This seems like an objectionable outcome, and yet one that FEO cannot condemn. And as Debra Satz has pointed out, this is just the tip of the iceberg. ${ }^{45}$ There are many ways in which childrearing and socialization determine one's willingness to put forth effort, and it seems awfully troubling for a political morality to offer nothing to those who through their childrearing and socialization wind up with very little willingness to put forth effort.

I do not have anything original to say by way of response to this objection, I'm afraid. I'll simply endorse what Satz and Arneson have already said, which is that FEO can be supplemented with other principles that can condemn at least some

\footnotetext{
${ }^{45}$ Satz, "Unequal Chances: Race, Class and Schooling", Theory and Research in Education 10 (2012): $155-70$ at 160.
} 
of these effects of childrearing and socialization or can be expanded so as to issue this condemnation itself. ${ }^{46}$

The second childrearing objection is more disconcerting. Suppose we agree that childrearing practices are a significant determinant of the level of opportunity to succeed in the meritocracy that a child will have upon entering majority. If we accept broad parental liberty, as I have argued that we should, then we believe that the state should refrain from interfering with many of these practices. Once again, then, a feature of our actual world presents a problem for FEO.

But this doesn't have to spell the end of the ideal of fair equality of opportunity. If parents took it upon themselves to forgo the activities that would otherwise give their children advantages over other similarly endowed children, then FEO could yet be achieved. So it seems that they're obligated to do so.

Mason, who provides the most forceful instance of this objection, anticipates the likely response: Parents have either special obligations to, or special prerogatives with respect to, their children, and these obligations/prerogatives make it permissible or perhaps even obligatory for them to do the things that have the side effect of giving their children advantages over other similarly endowed children. But Mason points out, by way of rejoinder, that even if we concede this it still seems that FEO implies that parents have a strong reason to refrain from these activities. And this is still quite counterintuitive. ${ }^{47}$

I prefer to make a different response to this objection, though again one that Mason anticipates. I contend that FEO grounds neither an obligation nor a reason for parents to refrain from conferring competitive advantages on their children, since FEO is a principle of political morality and therefore is binding only on states. By

\footnotetext{
${ }^{46}$ Satz, ibid., pp. 160-1; Arneson, "Against Rawlsian Equality of Opportunity”, p. 79.

${ }^{47}$ Mason, "Equality of Opportunity and Differences in Social Circumstances", Philosophical Quarterly 54, no. 216 (Jul. 2004): 368-88 at 369-72.
} 
way of rejoinder, Mason insists that considerations of social justice apply to the basic structure of society and that the family is part of that structure. (Here Mason cites Cohen's work.)

At this point it becomes difficult to conduct a dialogue with Mason, since I never set out to demonstrate that FEO was an element of justice; rather I set out to demonstrate that FEO is an element of the true political morality. But I don't want to escape Mason's objection on a technicality, and fortunately I have a way of making my point that doesn't appeal to a distinction between justice and political morality.

The most obvious reason why FEO cannot be binding on individuals is that it is based on an ideal that applies only to states. That ideal, again, is the ideal of a level playing field. It may be - and I certainly hope it is - compelling to suppose that it is the job of the state to ensure a level playing field. But I see no appeal to the idea that individuals should level the playing field or even strive towards its being leveled. In this way, leveling the playing field is like providing national defense, securing clean drinking water, or setting aside wild areas for recreational purposes: they're activities that don't even register on our moral radar until we begin to think about what the state morally ought to do. ${ }^{48,49}$

This isn't to deny that activities within the family constitute part of the basic structure and are thus subject to principles of justice/political morality. But there is an important ambiguity in the idea of an activity's being subject to principles of justice/political morality. On the one hand it might mean that the state may legitimately regulate those activities in the ways necessary to uphold the relevant

\footnotetext{
${ }^{48}$ Mason anticipates a move quite similar to this; specifically, he anticipates his opponent pointing out that an individual is in no position to be able to judge how to advance FEO (ibid., pp. 372-3). This isn't quite the move I want to make, though I think that it may stem from the correct initial thoughtthe idea that the level playing field ideal is not an ideal for individuals — and simply take that thought in the wrong direction.

${ }^{49}$ One might doubt that the moral requirements that apply to states could fail to coincide perfectly with the moral requirements that apply to individuals. I argue that that they can; see Sachs, "Contractarianism as a Political Morality," forthcoming in Proceedings of the Aristotelian Society.
} 
principle of justice/political morality. On the other hand it may mean that the individuals who engage in those activities have obligations, grounded in the relevant principles of justice/morality, to moderate their activities accordingly. I am merely denying that activities constitutive of the family are subject to principles of justice/political morality in the latter sense. So in at least one sense, the former sense, I can and do concede that activities within the family, including the activities by which parents confer competitive advantages on their children, are subject to principles of justice/political morality. (Though of course I take FEO to have merely pro tanto force and therefore the question of whether the state ought to restrict parents in this way depends, for me, on the relative weight of FEO and parental liberty. ${ }^{50}$ )

Furthermore, given my claim that FEO is part of the true political morality I can say that the state does wrong insofar as it fails to regulate parental activities in whatever way is necessary to secure FEO. This allows me to make a case, based on the intuition that one ought not to take advantage of the wrongdoing of others, that when the state ought to ban a certain parental activity but fails to do so it is wrong for parents to engage in that activity. So, for instance, I could concede to Adam Swift that it is wrong of parents to send their children to private schools. ${ }^{51}$ But this would not amount to committing myself to the very counterintuitive claim that parents are obligated in general to forgo the activities that would otherwise give their children advantages over other similarly endowed children.

Mason has one final bullet in the chamber: an appeal to a case-specific intuition. He says, "If, for example, male heads of families forbid their daughters from receiving a formal education, this surely violates principles of equality of

\footnotetext{
${ }^{50}$ See and Brighouse and Swift ("Parents' Rights and the Value of the Family", "Legitimate Parental Partiality", and Family Values Part Three) for one view on how this balance should be struck.

${ }^{51}$ Adam Swift, "The Morality of School Choice Reconsidered: A Response," Theory and Research in Education 2 (2004): 323-42.
} 
opportunity even if educational institutions in the wider society do not discriminate against women." 52

One thing Mason might mean is that the outcome designated as desirable by FEO could not be instantiated under the given circumstances. This would be true but beside the point; the question is who is obligated to bring about the designated outcome. What Mason must mean, then, is that the actions of male heads of families in such a society violate fair equality of opportunity. I admit that I have something in the neighborhood of this intuition; I have the intuition that the male heads of families in this society are violating an obligation. But I don't have the intuition that they're violating an FEO-based obligation. And I think I'm not alone here. Take the average person and confront her with a vignette like this and what she's likely to say, I suspect, is that the fathers are wronging their daughters by failing to do what parents are obligated to do- - e.g., not compromise the open future that their children might otherwise enjoy. FEO wouldn't enter in to it. ${ }^{53}$

\section{Conclusion}

In this essay I've laid out a highly specified version of the principle of fair equality of opportunity, argued for it and defended it against objections. My version of FEO resolves certain ambiguities that remain from Rawls's work; in particular it says that FEO is to regulate opportunities for jobs and offices as opposed to opportunities for broader goods such as success or achievement. Furthermore, I've claimed that since

\footnotetext{
${ }^{52}$ Mason, "Equality of Opportunity and Differences in Social Circumstances," p. 372

${ }^{53}$ Elsewhere Mason amends the thought experiment with the further stipulation that the father does not prohibit his son(s) from receiving an education (Mason, Living Together as Equals (Oxford: Oxford University Press, 2012), p. 122). Mason suspects that with this feature stipulated, we'll have the intuition that there's a comparative wrong — violation of equality of opportunity - being committed here as opposed to just the non-comparative wrong of depriving one's child of an open future. Again, I have something like the intuition Mason expects us to have. But the comparative wrong that the father has committed here, it seems to me, is that wrong of playing favorites with his children.
} 
FEO regulates the distribution of opportunities for jobs and offices, as opposed to jobs and offices themselves, we can understand how there could be a place for FEO in a meritocratic world: the principle should be understood as requiring equal opportunity to succeed in the meritocracy. In addition I've offered an original understanding of what succeeding in the meritocracy amounts to and why it's good. Succeeding in the meritocracy means obtaining the right job or office-one that calls upon the use of one's refined talents - and is good in virtue of constituting the avoidance of a soul-crushing bad, the bad of spending one's working days doing something that one finds uninteresting. These moves then allowed me to offer novel defenses of FEO against the most troubling challenges to which it has been subjected. 